REFLEKSI HUKUM

Jurnal Imu Hukum
p-ISSN 2541-4984 | e-ISSN 2541-5417

Volume 6 Nomor 1, Oktober 2021, Halaman 1-18

DOI: https://doi.org/10.24246/jrh.2021.v6.i1.p1-18

Open access at: http:// journal.uksw.edu/refleksihukum

Penerbit: Fakultas Hukum Universitas Kristen Satya Wacana

\title{
PERANAN AUTOPSI FORENSIK DAN KORELASINYA DENGAN KASUS KEMATIAN TIDAK WAJAR
}

\author{
Widowati \\ Fakultas Hukum Universitas Tulung Agung | widowati.p4@gmail.com
}

Y.A. Triana Ohoiwutun

Fakultas Hukum Universitas Jember | trianaohoiwutun@unej.ac.id

Fiska Maulidian Nugroho

Fakultas Hukum Universitas Jember | n.f.fiska@gmail.com

Samsudi

Fakultas Hukum Universitas Jember | samsudiborju.fh@unej.ac.id

\section{Godeliva Ayudyana Suyudi}

Fakultas Hukum Universitas Jember | godeliva98@gmail.com

\begin{abstract}
A R T I C L E I N F O
Article history:

Received

22 Februari 2021

Revised

6 Maret 2021

Accepted

11 Oktober 2021

Kata-kata Kunci:

Hukum positif;

Autopsi forensik;

Kematian tidak wajar.

Abstrak

Autopsi forensik tidak dapat dilepaskan dari tujuan utama penemuan penyebab pasti kematian seseorang. KUHP Pasal 222 dan KUHAP Pasal 133 dan 134, telah mengatur mengenai autopsi forensik. Adanya ketentuan mengenai pemberitahuan kepada keluarga korban untuk dilakukannya autopsi forensik, merupakan kendala tersendiri di dalam implementasinya, yang justru menghambat penegakan hukum dalam kasus-kasus kematian yang tidak wajar. Padahal, hanya melalui autopsi forensik suatu kebenaran materiil dapat diungkap kebenarannya secara ilmiah, baik pada saat dimulainya penyelidikan perkara sampai dengan pembuktian perkara di pengadilan. Beberapa kasus dan putusan pengadilan yang telah berkekuatan hukum tetap mengindikasikan mengenai pentingnya posisi autopsi forensik dalam pembuktian kasus-kasus kematian yang diformulasikan sebagai tindak pidana materiil. Oleh karena itu, dalam kasus-kasus kematian tidak wajar, seyogianya pelaksanaan autopsi forensik tidak harus menunggu persetujuan keluarga korban demi tercapainya kepastian hukum yang adil, baik bagi korban, pelaku maupun masyarakat.
\end{abstract}

\section{Keywords:}

Positive law; Forensic autopsy; Unnatural death.

\footnotetext{
Abstract

A forensic autopsy aims to find a definite cause of a person's death by revealing the material truth scientifically from the beginning of case investigation to its trial examination. In judicial practices, a forensic autopsy is considered a pivotal tool in proving material criminal acts. However, KUHP Article 222 and KUHAP Article 133-134 regulate forensic autopsy procedures requiring prior notification to the victim's family. These provisions have hindered law enforcement in certain unnatural death cases. Therefore, this article encourages forensic autopsy implementation must not wait for a family consent of a victim for the sake of fair legal certainty to the victims, perpetrators, and also for society.
} 


\section{PENDAHULUAN}

Autopsi atau bedah mayat dikenal di dunia medis, yang secara umum dipahami sebagai tindakan pembedahan tubuh manusia yang telah mati. Menurut Kamus Kedokteran, autopsi (autopsy) adalah pemeriksaan postmortem dari sesosok mayat untuk menentukan sebab kematian atau sifat-sifat perubahan patologis, necropsy. ${ }^{1}$ Peraturan Pemerintah Nomor 18 Tahun 1981 tentang Bedah Mayat Klinis Dan Bedah Mayat Anatomis Serta Transplantasi Alat Dan Atau Jaringan Tubuh Manusia dan Surat Edaran Menteri Kesehatan Nomor 1342/MENKES/SE/XII/2001 tentang Pelaksanaan Autopsi Forensik (selanjutnya disebut SE Menkes Tahun 2001) merupakan ketentuan mengenai autopsi forensik yang berlaku di Indonesia.

Merujuk pada Peraturan Pemerintah Nomor 18 Tahun 1981 dan SE Menkes Tahun 2001 sebagaimana tersebut di atas, dapat diketahui mengenai jenis tindakan autopsi atau bedah mayat, meliputi: bedah mayat klinis, bedah mayat anatomis dan bedah mayat forensik. Adanya perbedaan mengenai jenis bedah mayat berhubungan dengan hakikat dan tujuan dilaksanakannya tindakan pembedahan itu sendiri. Bedah mayat yang berhubungan dengan pembuktian perkara hukum disebut bedah mayat forensik atau autopsi forensik. Terkait dengan tulisan ini, kajian mengenai bedah mayat difokuskan pada tindakan bedah mayat forensik atau selanjutnya menggunakan istilah autopsi forensik yang menduduki posisi penting dalam penegakan hukum, baik hukum pidana maupun hukum perdata.

Dari perspektif hukum pidana, tindak pidana kejahatan terhadap tubuh dan/atau nyawa di dalam Kitap Undang - Undang Hukum Pidana (selanjutnya disebut KUHP) diformulasikan sebagai tindak pidana materiil atau disebut juga delik materiil. Formulasi tindak pidana secara materiil berkonsekuensi yuridis di dalam pembuktian perkara, yaitu antara perbuatan terdakwa disyaratkan harus ada hubungan kausal dengan akibat yang dilarang undang-undang atau ada hubungan sebab-akibat antara perbuatan tertentu dengan akibat yang dilarang. Khusus pada tindak pidana yang berakibat pada kematian sesorang yang tidak wajar, mekanisme dalam pembuktian dilakukan dengan cara pemeriksaan kedokteran forensik atas mayat.

Hasil akhir proses pemeriksaan atas mayat seseorang yang berhubungan dengan peristiwa pidana, dituangkan dalam bentuk surat, yaitu visum et repertum atas mayat. Pemeriksaan atas mayat dalam pembuatan visum et repertum dapat dilakukan melalui 2 (dua) cara, yaitu pemeriksaan luar mayat dan pemeriksaan dalam mayat (bedah mayat/autopsi forensik). ${ }^{2}$ Bedah mayat forensik merupakan cara untuk menemukan penyebab pasti kematian seseorang, dan hanya melalui bedah mayat forensik penyebab pasti kematian seseorang dapat diungkap dan diketemukan. ${ }^{3}$ Namun demikian, dalam penegakan hukum, bedah mayat forensik tidak selalu dilakukan dalam kasus kematian atau berhubungan dengan peristiwa pidana. Tidak dilakukannya autopsi forensik tidak berakibat pada bebasnya

Difa Danis, Kamus Istilah Kedokteran (ed.1, Gitamedia Press 2009) 66.

Y.A. Triana Ohoiwutun, Imu Kedokteran Forensik Interaksi dan Dependensi Hukum Pada Imu Kedokteran (ed. 1, Pohon Cahaya 2016) 14.

$3 \quad$ Ibid., 30. 
terdakwa dari pertanggungjawaban pidana atas kejahatan yang dilakukannya, apabila terdakwa memang terbukti bersalah melakukan tindak pidana berdasarkan fakta hukum yang terungkap di persidangan. Menurut hemat penulis, dari perspektif hukum pidana, tidak adanya autopsi forensik dalam kasus kematian, dapat dikatakan tidak memenuhi tujuan kebenaran materiil sebagaimana dituju di dalam setiap proses pemeriksaan perkara pidana, dan hal ini menarik untuk dikaji dan dicermati. Padahal, undang-undang menjamin dapat terlaksananya autopsi forensik dalam kasus kematian yang diduga disebabkan karena peristiwa pidana.

Regulasi dan urgensi autopsi forensik ditentukan di dalam Pasal 222 KUHP, dan Pasal 133 dan Pasal 134 Undang-Undang Nomor 8 Tahun 1981 tentang Kitab Undang-undang Hukum Acara Pidana (selanjutnya disebut KUHAP) sebagai sumber utama hukum pidana formil di Indonesia. Pada kedua undang-undang itulah secara tegas diatur mengenai urgensi autopsi forensik, dengan segala akibat hukumnya. Namun demikian, autopsi forensik tidak selalu dapat dilaksanakan dalam praktik penegakan hukum dalam kasus-kasus kematian. Alasan klasik adanya keberatan dari pihak keluarga menjadikan autopsi forensik tidak dilaksanakan oleh aparat penegak hukum, khususnya penyidik Polri.

Penulis mensinyalir, urgensi autopsi forensik belum banyak dipahami, meskipun peraturan perundangan telah mengaturnya. Tidak dilakukannya autopsi forensik dengan dalih atau alasan apapun, pada kasus-kasus kematian yang tidak wajar, berpotensi menjadi preseden buruk penegakan hukum di masa yang akan datang. Tulisan ini mencoba menguraikan mengenai ketentuan hukum yang berhubungan dengan autopsi forensik dan prospektif penegakan hukumnya.

Posisi autopsi forensik berada pada fase pra-ajudikasi dalam sistem peradilan pidana, dan penyidik Polri-lah yang berwenang dan bertanggungjawab penuh dalam tugas pelaksanaannya. Sebelum sampai pada fase penyidikan perkara, tindakan kepolisian diawali dengan penyelidikan perkara. Dengan bantuan ilmu kedokteran forensik suatu kejahatan terhadap tubuh atau nyawa dapat ditentukan untuk dilanjutkan atau dihentikan ${ }^{4}$ dalam proses perkaranya. Intervensi disiplin ilmu lain di luar hukum pidana (dalam hal ini ilmu kedokteran forensik), tidak dapat dilepaskan dari tujuan pemeriksaan perkara pidana, yaitu penemuan kebenaran materiil atau kebenaran yang sejati, dan dalam kasus kematian pemeriksaan autopsi forensik menduduki posisi penting di dalam pembuktian perkara guna menemukan penyebab kematian.

Kematian korban yang disebabkan karena tindakan kekerasan orang lain atau mati secara alamiah (natural death), dapat diketahui dari bedah mayat forensik. ${ }^{5}$ Posisi penting dan strategis autopsi forensik tidak hanya semata-mata berhubungan dengan menguak misteri penyebab kematian seseorang, namun demikian dari perspektif hukum pidana, eksistensi autopsi forensik berhubungan pula dengan penentuan kesalahan terdakwa. Adanya hubungan kausal antara perbuatan terdakwa dengan akibat kematian korban itulah parameter dalam

Y.A. Triana Ohoiwutun, 'Urgensi Pemeriksaan Kedokteran Forensik pada Fase Penyelidikan dan Penyidikan Perkara Pidana' (2014) 1 (2) Jurnal Cendekia Waskita 109.

Kastubi, 'Fungsi Bedah Mayat Forensik (Autopsi) Untuk Mencari Kebenaran Materiil Dalam Suatu Tindak Pidana' (2016) 13 (1) Jurnal Spektrum Hukum 73. 
menentukan kesalahan terdakwa yang berkorelasi dengan pertanggungjawaban pidana.

Perihal bedah mayat forensik atau autopsi forensik belum banyak ditulis, namun demikian, sebagai bahan kajian konseptual, penulis memandang penting untuk menyertakan beberapa tulisan yang membedakan tulisan konseptual ini dengan penulis terdahulu. Tulisan berjudul 'Bedah Mayat dan Akibat Hukumnya' ditulis oleh Yukilfi Poluan dengan hasil kajian bedah mayat bertujuan menentukan penyebab kematian, baik untuk kepentingan ilmu kedokteran maupun menemukan misteri kematian yang disebabkan oleh peristiwa pidana, dengan kajian berdasarkan Undang-Undang Nomor 36 Tahun 2009 tentang Kesehatan (selanjutnya disebut UU Kesehatan), dan Peraturan Pemerintah Nomor 18 Tahun 1981 tentang Bedah Mayat Klinis dan Bedah Mayat Anatomis serta Transplantasi Alat atau Jaringan Tubuh Manusia. ${ }^{6}$ Tulisan Yukilfi Poluan berbeda dengan tulisan ini, karena tulisan ini mengkaji secara spesifik mengenai eksistensi autopsi forensik dari perspektif KUHP, KUHAP, UU Kesehatan dan beberapa peraturan pelaksana teknis lainnya.

Tulisan lain terkait dengan autopsi forensik ditulis oleh Kastubi, menguraikan mengenai urgensi bedah mayat forensik yang dihubungkan dengan pencarian dan penemuan kebenaran materiil di dalam hukum pidana, menguraikan secara umum mengenai visum et repertum dan pertanggungjawaban hukum dalam pembuatan visum et repertum. ${ }^{7}$ Meskipun autopsi forensik merupakan bagian dari proses dalam pembuatan visum et repertum, namun yang membedakan tulisan Kastubi dengan tulisan ini, terletak pada uraian dan kajian mengenai ketentuan hukum yang mengatur mengenai autopsi forensik, dan korelasi autopsi forensik dalam kasus kematian yang tidak wajar dari perspektif hukum pidana.

Pentingnya autopsi forensik dalam rangka membuktikan adanya perbuatan turut serta dalam pembunuhan berencana pernah ditulis oleh Y.A. Triana Ohoiwutun dengan menguraikan mengenai pentingnya autopsi forensik dalam menentukan pertanggungjawaban pidana dalam tindak pidana pembunuhan berencana yang dilakukan secara bersama-sama dengan fokus kajian khusus mengenai Putusan Pengadilan Negeri Bogor Nomor 79/Pid.B/2012/PN.BGR. ${ }^{8}$ Sifat lebih luasnya tulisan ini yang membedakannya dengan tulisan terdahulu, karena kajian dalam tulisan ini bersifat umum mengenai pelaksanaan autopsi forensik berdasarkan hukum positif Indonesia dan kendala penerapan hukumnya, artinya tulisan ini tidak hanya terfokus pada satu kasus tertentu, melainkan mengembangkan secara umum mengenai autopsi forensik dari perspektif hukum Indonesia.

Tulisan lain terkait dengan autopsi forensik ditulis pula oleh Putu Pradnyasanti Laksmi, dkk, menguraikan mengenai faktor-faktor yang memengaruhi penolakan dilakukannya autopsi forensik pada kasus kematian tidak wajar dengan meneliti sejumlah 89 responden, dengan hasil penelitian $87,6 \%$

Yukilfi Poluan, 'Bedah Mayat dan Akibat Hukumnya' (2014) 3 (4) Jurnal Lex Crimen 124, 129. Kastubi (n 5) 87.

Y. A. Triana Ohoiwutun, 'Urgensi Bedah Mayat Forensik Dalam Pembuktian Tindak Pidana Pembunuhan Berencana Kajian Putusan Nomor 79/Pid.B/2012/PN.BGR' (2016) 9 (1) Jurnal Yudisial 73, 92. 
menolak autopsi dan 88,5\% menolak proses perkara dilanjutkan melalui jalur hukum. 9 Data secara kuantitatif yang menggambarkan faktor-faktor yang mempengaruhi penolakan autopsi forensik sebagaimana hasil penelitian Putu Pradnyasanti Laksmi, dkk tidak diuraikan dalam tulisan ini, karena tulisan ini mengarah pada analisis secara kualitatif mengenai urgensi autopsi forensik dan kendala penerapan hukumnya dalam kasus kematian.

Tulisan berjudul 'Peranan Autopsi Forensik dan Korelasinya Dengan Kasus Kematian Tidak Wajar' mencoba melengkapi tulisan yang telah ada sebelumnya, dengan rumusan masalah yang merupakan fokus kajian sebagai berikut:

1) Apakah peraturan perundangan telah memberikan kepastian hukum tindakan autopsi forensik dalam kasus kematian tidak wajar?

2) Apakah peran dan fungsi autopsi forensik dalam pembuktian perkara kasus kematian tidak wajar?

\section{PEMBAHASAN}

\section{Ketentuan Peraturan Perundang-Undangan dalam Memberikan Kepastian Hukum Tindakan Autopsi Forensik dalam Kasus Kematian Tidak Wajar}

Berbicara masalah hukum positif, kita tidak dapat melepaskan diri dari asas legalitas sebagai basis dalam menentukan ada atau tidaknya perbuatan bersifat melawan hukum yang ditentukan sebelumnya di dalam undang-undang. Sebagaimana dikemukakan oleh Simons, van Hamel dan van Hattum, bahwa manfaat dari asas legalitas untuk menjamin kepastian hukum, sedangkan Vos menyatakan, bahwa asas legalitas bermanfaat sebagai alat pencegah umum ancaman pidana dalam menjamin kepastian hukum. ${ }^{10}$ KUHP, KUHAP, UU Kesehatan dan beberapa peraturan teknis lainnya merupakan ketentuan hukum positif yang mengatur mengenai autopsi forensik, yang bertujuan untuk memenuhi 'tuntutan' terwujudnya asas legalitas dalam menjamin adanya kepastian hukum.

Bedah mayat forensik secara terminologi merupakan penyelidikan atau pemeriksaan atas mayat, termasuk seluruh organ tubuhnya dan susunan pada bagian dalam tubuh, untuk tujuan menentukan penyebab kematian seseorang, baik untuk kepentingan ilmu kedokteran maupun menjawab misteri suatu tindak pidana. ${ }^{11}$ SE Menkes Tahun 2001 menyebutkan, bahwa autopsi forensik adalah tindakan pemeriksaan bedah mayat dengan cara membuka seluruh rongga kepala, leher, dada, perut dan panggul serta pemeriksaan lanjutan yang diperlukan, guna dapat menentukan sebab kematian dan memperoleh berbagai petunjuk lain yang berguna bagi penyidikan ataupun pembuktian di pengadilan.

Merujuk pada pengertian bedah mayat, dapat dikatakan, bahwa dalam konteks bedah mayat, dengan cara membuka seluruh bagian dalam tubuh mayat, baik kepala, leher, dada, perut dan panggul, tujuan utamanya untuk menentukan penyebab kematian seseorang. Dalam konteks autopsi forensik, bedah mayat

\footnotetext{
9 Putu Pradnyasanti Laksmi, IB Putu Alit, dan Henky, 'Deskripsi Faktor-Faktor Yang Memengaruhi Penolakan Otopsi Pada Kasus Kematian Yang Diduga Tidak Wajar' (2020) 9 (7) E-Jurnal Medika Udayana 86.

10 Fifink Praiseda Alviolita, 'Pertanggungjawaban Pidana Pengurus Korporasi Dikaitkan Dengan Asas Geen Straf Zonder Schuld' (2018) 3 (1) Jurnal Refleksi Hukum: Jurnal Ilmu Hukum 4.

$11 \quad$ Kastubi (n 5) 73.
} 
bertujuan untuk mendapatkan petunjuk guna kepentingan penegakan hukum, baik pada tahap penyelidikan, penyidikan, maupun pembuktian perkara di pengadilan.

Dalam kasus kematian tidak wajar yang diduga disebabkan karena peristiwa pidana, posisi autopsi forensik pada umumnya dimulai pada proses penyelidikan perkara oleh penyidik Polri. Manfaat autopsi forensik dalam kasus dugaan kematian tidak wajar, berperan penting bagi penyidik dalam memutuskan melanjutkan atau menghentikan proses penyidikan perkara, atau dapat dikatakan autopsi forensik sebenarnya adalah 'bekal utama' bagi penyidik untuk melanjutkan atau menghentikan penyelidikan dan kemudian penyidikan perkara kematian tidak wajar.

Hasil pemeriksaan autopsi forensik dituangkan di dalam surat, yaitu visum et repertum, namun demikian KUHAP tidak menyebutkan secara spesifik mengenai istilah visum et repertum sebagai alat bukti yang sah. Istilah visum et repertum ditentukan di dalam Staatsblad Tahun 1937 Nomor 350 tentang Visa Reperta. Visum et repertum merupakan bentuk tunggal dari Visa Reperta, yang dapat diterjemahkan secara bebas sebagai laporan yang dibuat berdasarkan penyaksian atau pengakuan telah melihat sesuatu. ${ }^{12}$ Terkait Staatsblad Tahun 1937 Nomor 350, pada intinya visum et repertum dokter, nilai daya buktinya hanya sebatas mengenai hal yang dilihat atau ditemukan dokter atas pemeriksaan terhadap korban atau dokter hanya dianggap memberikan kesaksian mata saja dan sah-nya visum et repertum bila dibuat oleh dokter yang telah mengucapkan sumpah jabatan sebagai dokter. ${ }^{13}$

Merujuk pada Staatsblad Tahun1937 Nomor 350, syarat mengenai kewajiban dokter pembuat visum et repertum telah mengucapkan sumpah jabatannya sebagai dokter, merupakan syarat formil yang harus dipenuhi oleh dokter. Ketentuan syarat formil dalam pembuatan visum et repertum, ditetapkan pula dalam Instruksi Kapolri Nomor PolINS/E/20/IX/75 tentang Tata Cara Permohonan/Pencabutan Visum et Repertum (selanjutnya disebut Instruksi Kapolri Tahun 1975), yang menyebutkan antara lain, dalam pembuatan visum etrepertum disyaratkan untuk didasarkan pada permintaan secara tertulis dari penyidik Polri. Ketentuan persyaratan permintaan secara tertulis dari penyidik Polri sejalan dengan ketentuan Pasal 133 ayat (2) KUHAP ${ }^{14}$ dan mengacu pada SE Menkes Tahun 2001.

Dalam permintaan tertulis penyidik untuk kepentingan pembuatan visum et repertum secara tegas harus menyebutkan untuk pemeriksaan luka atau pemeriksaan mayat atau pemeriksaan bedah mayat. ${ }^{15}$ Dalam praktiknya

Ohoiwutun, Imu Kedokteran Forensik (Interaksi dan Dependensi Hukum pada Ilmu Kedokteran) (n 2) 26.

13 Dedi Afandi, Visum et Repertum Tata Laksana dan Teknik Pembuatan (ed. 2, Fakultas Kedokteran Universitas Riau 2017) 3.

14 Pasal 133 KUHAP: Dalam hal penyidik untuk kepentingan peradilan menangani seorang korban baik luka, keracunan ataupun mati yang diduga karena peristiwa yang merupakan tindak pidana, ia berwenang mengajukan permintaan keterangan ahli kepada ahli kedokteran kehakiman atau dokter dan atau ahli lainnya; (2) Permintaan keterangan ahli sebagaimana dimaksud dalam ayat(1) dilakukan secara tertulis, yang dalam surat itu disebutkan dengan tegas untuk pemeriksaan luka atau pemeriksaan mayat dan atau pemeriksaan bedah mayat. Pelaksanaan autopsi forensik menurut SE Menkes Tahun 2001 antara lain disyaratkan harus ada permintaan secara tertulis dari penyidik yang secara tegas menyatakan untuk pemeriksaan luka atau pemeriksaan mayat atau pemeriksaan bedah mayat. 
permintaan pemeriksaan mayat berarti pemeriksaan dokter pembuat visum et repertum hanya dilakukan di luar tubuh mayat atau tanpa autopsi forensik; sedangkan pemeriksaan bedah mayat, berarti pemeriksaan mayat dilakukan melalui autopsi forensik.

Dalam pemeriksaan kasus kematian tidak wajar dengan dugaan adanya peristiwa pidana, ada atau tidaknya autopsi forensik bergantung sepenuhnya pada permintaan tertulis dari penyidik yang ditujukan pada sarana pelayanan kesehatan, baik puskesmas maupun rumah sakit sebagai tempat dilaksanakannya pemeriksaan mayat. Dokter sebagai pelaksana tugas dalam pembuatan visum et repertum bergantung sepenuhnya pada 'order' penyidik yang disebutkan secara tertulis. Dalam hal ini, apabila penyidik dalam surat permintaannya tidak menyebutkan pemeriksaan dalam mayat, maka dokter pembuat visum et repertum tidak melakukan autopsi atas mayat. Dapat dikatakan, tindakan pemeriksaan atas mayat dengan autopsi atau tanpa autopsi bergantung sepenuhnya pada permintaan tertulis penyidik.

Terkait dengan pemeriksaan atas mayat, sebagaimana disebutkan dalam Instruksi Kapolri Tahun 1975 bahwa pembuatan visum et repertum atas mayat, diwajibkan untuk dilakukannya autopsi forensik atau mayat harus dibedah, dan tidak dibenarkan hanya pemeriksaan luar mayat. ${ }^{16}$ Lebih lanjut disebutkan, bila keluarga korban keberatan dengan tindakan autopsi forensik, maka petugas Polri c.q. pemeriksa wajib menjelaskan secara persuasif tentang pentingnya autopsi forensik, dan bilamana perlu, untuk kepentingan penyidikan ditegakkan Pasal 222 KUHP. ${ }^{17}$ Merujuk pada Instruksi Kapolri Tahun 1975, autopsi forensik wajib dilaksanakan dalam pemeriksaan atas mayat, dan dibuka kemungkinan penerapan Pasal 222 KUHP apabila ada keberatan dari pihak keluarga.

Penerbitan Instruksi Kapolri Tahun 1975 dilatarbelakangi oleh kondisi belum seragamnya tata cara dan tata laksana prosedur dalam memperoleh visum et repertum. Secara substansi ada beberapa hal dari Instruksi Kapolri Tahun 1975 terkait dengan pembuatan visum et repertum yang dirujuk oleh KUHAP, khususnya Pasal 133 ayat (1), bahwa dalam hal penyidik menangani seorang korban luka, keracunan atau mati diduga karena peristiwa pidana, penyidik berwenang mengajukan permintaan keterangan ahli kepada ahli kedokteran kehakiman atau dokter dan atau ahli lainnya; dan ayat (2) permintaan keterangan ahli dilakukan secara tertulis dengan menyebutkan secara tegas untuk pemeriksaan luka atau pemeriksaan mayat dan atau pemeriksaan bedah mayat.

Terkait dengan pemeriksaan atas mayat, KUHAP Pasal 133 ayat (3) menentukan, bahwa mayat yang diperlukan untuk pemeriksaan kedokteran forensik, harus diperlakukan secara baik dengan penuh penghormatan dengan diberi label yang antara lain memuat identitas mayat. Di samping itu, KUHAP Pasal 134 ayat (1) menentukan bilamana autopsi tidak mungkin dihindari, maka ada kewajiban bagi penyidik untuk memberitahukan terlebih dahulu pada keluarga korban; dan ayat (2) apabila keluarga keberatan dengan dilakukannya bedah

16 Instruksi Kapolri Tahun 1975 angka 3 menyebutkan: Dalam hal seseorang yang menderita luka akhirnya meninggal dunia maka harus segera mengajukan surat susulan untuk meminta Visum et Repertum atas mayat, berarti mayat harus dibedah. Sama sekali tidak dibenarkan permintaan Visum et Repertum atas mayat berdasarkan pemeriksaan luar saja. 
mayat, maka penyidik wajib menjelaskan mengenai maksud dan tujuan dilakukannya autopsi; ayat (3) apabila dalam waktu dua hari tidak ada tanggapan dari keluarga atau pihak yang perlu diberitahu diketemukan, penyidik segera melaksanakan ketentuan Pasal 133 ayat (3).

Bertolak pada KUHAP Pasal 133 dan Pasal 134, adanya autopsi forensik bergantung pada ada atau tidaknya keluarga korban atau pihak yang menerima pemberitahuan untuk dilaksanakannya autopsi forensik. Apabila tidak ada pihak keluarga atau pihak yang menerima pemberitahuan untuk dilaksanakannya autopsi forensik, maka penyidik wajib melaksanakan ketentuan Pasal 133 ayat (3), yaitu memperlakukan mayat dengan penuh penghormatan. KUHAP Pasal 133 dan Pasal 134 tidak menentukan lebih lanjut untuk dilaksanakannya tindakan autopsi forensik apabila ada keberatan dari pihak keluarga. KUHAP Pasal 134 ayat (2) 'hanya' menentukan tugas dan kewajiban penyidik untuk menerangkan dengan sejelas-jelasnya tentang maksud dan tujuan dilaksanakannya autopsi forensik. Menurut hemat penulis, KUHAP Pasal 134, tidak memberikan alternatif penyelesaian apabila terjadi penolakan autopsi forensik oleh pihak keluarga korban, dan ketentuan memperlakukan mayat dengan penuh penghormatan menurut Pasal 133 ayat (3), sebagaimana ditentukan di dalam KUHAP Pasal 134 ayat (3) tidaklah dapat dimaknai bahwa autopsi forensik dapat dilaksanakan meskipun ada penolakan dari pihak keluarga korban. Ada inkonsistensi dalam KUHAP Pasal 134 terkait penerapan autopsi forensik, yang membuat kabur kasuskasus kematian tidak wajar, 18 dan tujuan penemuan kebenaran materiil tidak tercapai dalam kasus kematian yang tidak diautopsi.

Merujuk pada Instruksi Kapolri Tahun 1975, SE Menkes Tahun 2001, dan KUHAP Pasal 133 dan Pasal 134 menurut hemat penulis, terkait pelaksanaan autopsi forensik lebih bersifat prosedural dengan prasyarat adanya pemberitahuan pada pihak keluarga korban, dalam artian tidak mempunyai daya kekuatan mengikat sebagai hal yang memang wajib dilaksanakan untuk kepentingan pembuktian perkara kasus kematian. Prasyarat adanya pemberitahuan pada pihak keluarga namun ada penolakan dari pihak keluarga untuk dilaksanakannya autopsi forensik, dalam kasus-kasus tertentu mengandung kelemahan tersendiri, misalnya kasus pembunuhan dalam keluarga, yang pelakunya dari lingkup dalam keluarga. Upaya 'menutupi' atau 'melindungi' pelaku perkara pembunuhan dalam keluarga dapat dilakukan dengan cara menolak dilaksanakannya autopsi forensik terhadap korban, meskipun sudah ada pemberitahuan dan penjelasan dari penyidik tentang urgensi dilakukannya autopsi forensik sebagaimana diamanahkan Pasal 134 KUHAP. Dengan adanya penolakan tersebut dan autopsi forensik tidak dilaksanakan, kemungkinan penyebab kematian tetap menjadi misteri yang tidak akan pernah terungkap dan pelaku berpeluang 'lolos' dari pertanggungjawaban pidana.

Dalam beberapa putusan pengadilan yang telah berkekuatan hukum tetap, adanya keberatan dari pihak keluarga untuk dilakukannya autopsi forensik disertai dengan surat pernyataan dalam proses penyidikan perkara di kepolisian. Putusan pengadilan terkait kasus perkara kematian yang tidak disertai dengan

18 Amelia Fransiska Rompas, 'Kajian Yuridis Pasal 134 KUHAP tentang Bedah Mayat Dalam Penegakam Hukum Pidana Indonesia' (2015) 3 (1) Jurnal Lex et Societatis 140, 141. 
autopsi forensik karena ada penolakan dari pihak keluarga, antara lain dapat dilihat di dalam Putusan Pengadilan Negeri Padangsidempuan Nomor 486/Pid.Sus/2014/PN.PSP, Putusan Pengadilan Negeri Payakumbuh Nomor 40/Pid.Sus/2018/PN Pyh, Putusan Pengadilan Negeri Poso Nomor 2/Pid.B/2018/PN Pso, dan sebagainya. Dari contoh kasus tersebut, adanya penolakan dari pihak keluarga korban untuk dilaksanakannya autopsi forensik, tidak serta merta mempengaruhi proses penegakan hukum, dan apabila dapat dibuktikan adanya kesalahan terdakwa, maka hakim akan menjatuhkan sanksi pidana berdasarkan alat bukti yang sah. Dalam artian, meskipum tanpa autopsi forensik, berdasarkan alat bukti yang lain, apabila hakim yakin atas kesalahan terdakwa, maka terdakwa dinyatakan bersalah dan dijatuhi sanksi pidana.

Berkenaan dengan autopsi forensik, KUHP Pasal 222 mengancam sanksi pidana bagi siapapun yang dengan sengaja mencegah, menghalang-halangi atau menggagalkan pemeriksaan mayat forensik. Di samping itu, KUHP Pasal 216 ayat (1), melarang perbuatan yang dengan sengaja tidak menuruti perintah atau permintaan pejabat yang tugasnya mengawasi sesuatu atau pejabat berdasarkan tugasnya menurut undang-undang, demikian pula yang diberi kuasa untuk mengusut atau memeriksa tindak pidana; demikian pula siapapun yang dengan sengaja mencegah, menghalang-halangi atau menggagalkan tindakan guna menjalankan ketentuan undang-undang yang dilakukan oleh salah seorang pejabat tersebut.

Sehubungan tindakan autopsi forensik, apabila merujuk pada KUHP Pasal 222, menentukan bahwa setiap orang, baik ada maupun tidak ada hubungan keluarga, dilarang melakukan perbuatan mencegah, menghalang-halangi atau menggagalkan pemeriksaan autopsi forensik terhadap korban yang kematiannya diduga karena peristiwa pidana. Di samping itu, ancaman pidana juga dapat dijatuhkan terhadap dokter atau siapapun yang menolak perintah atau permintaan penyidik atau pegawai negeri yang sedang bertugas berdasarkan undang-undang, atau dalam hal ini dapat dikatakan, bahwa pelaksanaan autopsi forensik adalah perintah undang-undang. Bertolak dari ketentuan KUHP Pasal 222 dan Pasal 216, pada hakikatnya undang-undang menjamin dapat terlaksananya tindakan autopsi forensik. Oleh karena itu, aparat penegak hukum, khususnya penyidik Polri yang bertanggung jawab dalam setiap pelaksanaan autopsi forensik dapat melakukan upaya paksa apabila ada ancaman, tantangan, hambatan atau gangguan dalam proses autopsi forensik.

Aturan lain terkait dengan autopsi forensik ditentukan di dalam Pasal 122 UU Kesehatan, yang pada intinya menentukan pada ayat (1) autopsi forensik dapat dilakukan untuk kepentingan penegakan hukum berdasarkan peraturan perundangan; dan ayat (2) autopsi forensik dilakukan oleh dokter ahli forensik, atau dokter lain apabila tidak ada dokter ahli forensik. ${ }^{19}$ Ada konsistensi antara Pasal 133 ayat (1) KUHAP dan Pasal 122 ayat (2) UU Kesehatan sepanjang mengatur mengenai peran dokter dalam pemeriksaan kedokteran forensik, yaitu

19 Pasal 122 UU Kesehatan: untukkepentingan penegakan hukumdapat dilakukanbedah mayat forensik sesuai dengan ketentuanperaturan perundang-undangan; ayat (2) bedah mayat forensik sebagaimana dimaksud padaayat (1) dilakukan oleh dokterahliforensik, atauoleh dokter lain apabila tidak ada dokter ahli forensikdanperujukan ketempat yang adadokter ahli forensiknyatidak dimungkinkan. 
pemeriksaan kedokteran forensik dapat dilakukan oleh dokter ahli forensik atau dokter lain apabila tidak ada dokter ahli forensik. Dalam artian keterlibatan dokter ahli forensik dalam pemeriksaan autopsi forensik bersifat kondisional, artinya apabila tidak ada dokter ahli forensik, pada hakikatnya setiap dokter diberikan kewenangan dalam pemeriksaan autopsi forensik. Ketentuan kewenangan setiap dokter (yang bukan ahli forensik) dalam pemeriksaan autopsi forensik bersifat logis, karena setiap dokter pernah melakukan autopsi anatomi ketika menempuh pendidikan dokter. Adapun ketentuan mengenai peran dokter dalam pemeriksaan kedokteran forensik juga ditentukan secara konsisten, baik menurut Instruksi Kapolri Tahun 1975, maupun SE Menkes Tahun 2001.

Bertolak pada KUHP, KUHAP, UU Kesehatan, Instruksi Kapolri Tahun 1975, dan SE Menkes Tahun 2001, pada hakikatnya undang-undang menjamin terlaksananya autopsi forensik untuk kepentingan penegakan hukum, dan pelaksanaannya hanya dapat dilakukan oleh profesi dokter dengan melibatkan peran penyidik Polri sebagai instansi yang bertanggung jawab dalam penyidikan perkara kasus kematian tidak wajar. Hal ini sejalan dengan Staatsblad Tahun 1937 No. 350, bahwa hanya tenaga medis ${ }^{20}$ atau dokterlah yang berwenang dalam pembuatan visum et repertum.

Undang-undang tidak menentukan lebih lanjut terkait dengan status kepegawaian dokter pembuat visum et repertum, apakah dokter PNS, dokter non PNS, atau dokter yang berstatus anggota militer. Menurut hemat penulis, meskipun undang-undang tidak menentukan mengenai status kepegawaian dokter dalam pembuatan visum et repertum, seyogianya dokter berstatus PNS atau dokter anggota militer yang berperan dalam pembuatan visum et repertum. Bagaimanapun, pembuatan visum et repertum berhubungan secara tidak langsung dengan dibukanya kondisi kesehatan seseorang yang mungkin dirahasiakan, sehingga rentan dijadikan alasan bagi keluarga atau pihak-pihak tertentu yang merasa dirugikan dengan pembuatan visum et repertum untuk menuntut atau menggugat dokter. Dokter yang berstatus PNS atau anggota militer, dapat berlindung berdasarkan KUHP Pasal 50 tentang perlindungan hukum bagi setiap orang yang melaksanakan ketentuan undang-undang atau KUHP Pasal 51 tentang perlindungan hukum bagi setiap orang yang melaksanakan perintah jabatan. KUHP Pasal 50 dan Pasal 51 dapat digunakan dokter yang berstatus sebagai PNS atau anggota militer apabila ada tuntutan atau gugatan dengan dilakukannya autopsi forensik yang dituangkan dalam visum et repertum.

Terkait dengan kasus kematian, autopsi forensik adalah dasar dari pembuatan kesimpulan di dalam visum et repertum atas mayat. Memang, visum et repertum tidak mampu menunjukkan siapa pelaku kejahatan yang mengakibatkan kematian korban, tetapi visum et repertum berpengaruh dalam penjatuhan sanksi terhadap pelaku;21 dan keberadaan autopsi forensik dapat difungsikan sebagai parameter dalam menentukan pertanggungjawaban pidana terhadap pelaku.

20 Pasal 11 ayat (2) UU No. 36 Tahun 2014 tentang Tenaga Kesehatan tenaga medis terdiri atas dokter, dokter gigi, dokter spesialis, dan dokter gigi spesialis.

Lisdayanty, 'Kedudukan Visum et Repertum Dalam Pengungkapan Delik Pembunuhan di Wilayah Hukum Polrestabes Makassar' (2019) 2 (2) Jurnal Phinisi Integration Review 271, 273. 
Menurut Abdul Mun'im Idries, ${ }^{22}$ dengan autopsi forensik dapat mengungkap dan mengetahui kejelasan penyebab matinya seseorang, cara-cara kematian, pembunuhan, bunuh diri atau kecelakaan atau mati dikarenakan suatu penyakit. Bertolak dari pendapat Abdul Mun'im Idries, jelaslah hanya dengan autopsi forensik tabir penyebab kematian dapat diuraikan dan diungkap secara ilmiah menurut ilmu kedokteran yang telah teruji kebenarannya.

\section{Peran Dan Fungsi Autopsi Forensik Dalam Pembuktian Perkara Kasus Kematian Tidak Wajar}

Dari perspektif ilmu kedokteran, secara umum dibedakan cara kematian, yaitu wajar atau tidak wajar. Dalam kematian wajar dikarenakan penyakit atau usia tua, dan kematian tidak wajar dikarenakan berbagai kekerasan (pembunuhan, bunuh diri, kecelakaan kerja atau kecelakaan lalu lintas), kematian akibat tindakan medis, tenggelam, intoksikasi, dan kematian yang tidak jelas penyebabnya. ${ }^{23}$ Bertolak dari kematian tidak wajar itulah, pemeriksaan autopsi forensik diperlukan guna menentukan ada atau tidaknya peristiwa pidana dalam suatu kasus.

Peristiwa kematian di dalam KUHP yang diformulasikan sebagai tindak pidana materiil, konsekuensinya adalah adanya hubungan kausal antara perbuatan pelaku dengan akibat yang dilarang undang-undang haruslah dapat dibuktikan. Oleh karena itu, berbicara masalah kematian yang disebabkan karena peristiwa pidana, berarti dalam kajiannya berkorelasi dengan ajaran kausalitas sebagai dasar dalam menentukan pertanggungjawaban pidana. Teori hubungan kausalitas sangat penting dalam menentukan pertanggungjawaban untuk delikdelik yang dirumuskan secara materiil, karena akibat yang ditimbulkan merupakan unsur delik, ${ }^{24}$ dalam hal ini penyebab kematian yang dikarenakan perbuatan seseorang itulah yang seharusnya dapat dibuktikan dalam menentukan adanya kesalahan dan pertanggungjawaban pidana.

Ajaran kausalitas (causation) dalam hukum pidana digunakan untuk menemukan pertanggungjawaban pidana dalam jenis tindak pidana yang menghasilkan akibat yang dilarang, artinya sebuah tindak pidana baru bisa dimintakan pertanggungjawaban pidana jika konsekuensi perbuatan tersebut muncul, ${ }^{25}$ atau menimbulkan akibat yang dilarang oleh undang-undang. Dalam kasus-kasus kematian kadang tidak mudah untuk menentukan hubungan kausal antara perbuatan tertentu yang mengakibatkan kematian seseorang, dan pemeriksaan autopsi forensik merupakan simpul utama dalam mengurai dan mengungkap suatu misteri kematian.

Kasus-kasus kematian yang menimbulkan polemik berkepanjangan di Indonesia yang tidak mudah dalam pembuktian perkara untuk menentukan pertanggungjawaban pidana, antara lain pada kasus kematian Munir tahun 2004, Kematian Munir (ed. 1, Mizan Publika 2013) 104.

23 Henky, Kunthi Yulianti, Ida Bagus Putu Alit, Dudut Rustyadi, Buku Panduan Belajar Koas Imu Kedokteran Forensik dan Medikolegal (cet. 1, Udayana University Press 2017) 3.

24 Eddy O.S. Hiariej, Prinsip-prinsip Hukum Pidana (ed. 2, Cahaya Atma Pustaka 2016) 207.

25 Ahmad Sofian, 'Ajaran Kausalitas dalam RKUHP' (Aliansi Nasional Reformasi KUHP, 1 April 2016) <http:// reformasikuhp.org/ajaran-kausalitas-dalam-r-kuhp/>diakses 17 Februari 2021. 
kasus kematian Nasruddin Zulkarnaen tahun 2009 dan kasus kematian Wayan Mirna Salihin. ${ }^{26}$ Dalam kasus-kasus dengan rantai penyebab panjang, tidak mudah menemukan perbuatan yang mengakibatkan kematian, sehingga sulit untuk menentukan pertanggungjawaban pidana terhadap pelaku, 27 meskipun ajaran kausalitas diberdayakan dalam membantu dan menentukan perbuatan yang menimbulkan akibat yang dilarang, namun dalam praktiknya tidak semudah yang dipikirkan. ${ }^{28}$ Tulisan ini tidak akan masuk dalam polemik dan kontroversi ketiga kasus tersebut, namun demikian, setidaknya dengan autopsi forensik, kematian tidak wajar yang dialami ketiga korban dapat ditemukan. Dari pemeriksaan autopsi forensik, penyebab kematian Munir dapat disimpulkan dikarenakan racun arsenicum, kematian Nasruddin Zulkarnaen disebabkan karena luka tembak, dan kematian Wayan Mirna Salihin disebabkan karena racun cianida. Kesimpulan dalam visum et repertum yang didasarkan pada autopsi forensik sebatas pada kesimpulan penyebab kematian ketiga korban, namun demikian, tidak dapat menyimpulkan pelaku yang menyebabkan kematian.

Dari perspektif kematian tidak wajar, dapat diberikan gambaran, dalam kasus yang dialami oleh seorang editor sebuah televisi swasta, yang mayatnya diketemukan 3 (hari) setelah kematiannya. Spekulasi terkait peristiwa kematian tidak wajar tersebut merebak ramai di media massa, dengan dugaan awal pembunuhan. Hasil pemeriksaan kedokteran forensik tidak ada pemukulan dan trauma benda tumpul pada tubuh korban, namun diketemukan tusukan dan sayatan di sekitar leher, yang berakibat pada kematian korban. ${ }^{29}$ Hasil pemeriksaan autopsi forensik sebagaimana di-release Kabid Humas Polda Metro Jaya, bahwa sebelum diketemukan, mayat korban telah berada di TKP antara dua sampai tiga hari dengan luka tusukan benda tajam pada leher dan dada yang berakibat fatal, luka tusuk pada dada menembus tulang iga dan paru-paru korban dan luka tusuk pada bagian leher yang mengakibatkan robek pada tenggorokan yang berakibat fatal pada kematian. ${ }^{30}$

Dari hasil olah TKP, bukti pendukung, keterangan lain, penyidik menyimpulkan kematian korban dikarenakan bunuh diri dengan cara menusukkan pisau yang dibelinya dari sebuah toko. ${ }^{31}$ Berdasarkan penyelidikan yang berbasis pada hasil pemeriksaan autopsi forensik dan didukung pemeriksaan psikologi forensik, dapat disimpulkan, bahwa kematian korban dikarenakan bunuh diri, dan tidak ada unsur peristiwa pidana di dalamnya, oleh karena itulah kemudian penyidik menghentikan proses pemeriksaan kasus tersebut.

\footnotetext{
26 Ahmad Sofian, Ajaran Kausalitas Hukum Pidana (cet.1, Prenada Media Group 2018) 2.

Ibid.

Ibid., 6.

Addina Zulfa Fa'izah, 'Tabir Gelap Kematian Editor Metro TV Fakta Baru Mulai Terungkap' (Merdeka, 22 Juli 2020) <https://www.merdeka.com/trending/tabir-gelap-kematian-editormetro-tv-fakta-baru-mulai-terungkap.html?page=7> diakses 13 Februari 2021.

30 Yogi Ernes, 'Polisi Ungkap Hasil Autopsi Jenazah Editor Metro TV yang Tewas di Ulujami' (DetikNews, 13 Juli 2020) <https://news.detik.com/berita/d-5091632/polisi-ungkap-hasilautopsi-jenazah-editor-metro-tv-yang-tewas-di-ulujami> diakses 13 Februari 2021.

31 Galih Priatmojo dan Bagaskara Isdiansyah 'Penyebab Kematian Editor Metro TV Terungkap, Keluarga Tak Yakin' (Suarajogja.id, 25 Juli 2020) <https://jogja.suara.com/read/2020/07/25/ $164000 /$ penyebab-kematian-editor-metro-tv-terungkap-keluarga-tak-yakin?page=all $>$ diakses 13 Februari 2021.
} 
Bertolak dari gambaran contoh kasus kematian editor televisi swasta tersebut, dari perspektif hukum acara pidana, autopsi forensik dapat dimanfaatkan secara strategis untuk menentukan kelayakan suatu kasus perkara kematian yang sedang diperiksa atau diselidiki untuk dilanjutkan pada proses penyidikan. Dari perspektif hukum pidana materiil, atau dalam hal ini tindak pidana yang diformulasikan secara materiil, autopsi forensik bermanfaat untuk menentukan adanya peristiwa pidana dan kemudian mengukur pertanggungjawaban pidana yang berbasis pada kesalahan pelaku.

Kasus kematian editor televisi swasta tersebut dapat disandingkan dengan Putusan Praperadilan Pengadilan Negeri Medan Nomor 85/Pid.Pra/2019/PN Mdn, dalam pokok perkara gugatan atas penghentian penyidikan kasus perkara kematian korban a.n. FS. Korban FS diketemukan meninggal tergantung di tokonya, dan mayatnya diketemukan 3 (tiga) hari setelah kematiannya. Atas permohonan keluarga, mayat korban tidak diautopsi, dan permohonan tersebut dikabulkan oleh penyidik.

Berdasarkan visum et repertum RS Bhayangkara Medan Nomor R/10/XII/2018 tertanggal 16 Januari 2019, disimpulkan, bahwa berdasarkan pemeriksaan luar, penyebab kematian korban tidak dapat ditentukan karena tidak diautopsi; dan berdasarkan keterangan dokter ahli forensik pembuat visum et repertum, bahwa kematian korban menunjukkan tanda-tanda mati gantung diri, dan penyebab pasti kematian korban tidak dapat ditentukan karena tidak diautopsi. Putusan Nomor 85/Pid.Pra/2019/PN Mdn dalam kesimpulannya menyatakan, bahwa perkara tersebut masih dalam proses penyelidikan dan sama sekali tidak pernah dilakukan penghentian penyidikan.

Bertolak dari kasus kematian editor televisi swasta dan Putusan Nomor 85/Pid.Pra/2019/PN Mdn, terkait dengan autopsi forensik, dapat disimpulkan, bahwa penghentian penyidikan dalam kasus peristiwa kematian yang berbasis pada pemeriksaan autopsi forensik "lebih" dapat diterima semua pihak, karena kesimpulan mengenai penyebab kematian dapat dipertanggungjawabkan secara ilmiah; sedangkan pemeriksaan perkara kematian yang tidak melalui autopsi forensik, di mana dalam kesimpulan visum et repertum dinyatakan bahwa penyebab kematian tidak dapat ditentukan, meskipun dari pemeriksaan luar ditemukan tanda-tanda mati gantung diri dalam Putusan Nomor 85/Pid.Pra/2019/PN Mdn, dan akibatnya perkara dinyatakan masih dalam penyelidikan. Merujuk pada dua peristiwa kematian tidak wajar tersebut, posisi autopsi forensik dapat dikatakan sebagai rujukan utama dalam menentukan berlanjut atau tidaknya penyelidikan perkara menuju ke tahap penyidikan. Atau dapat dikatakan, bahwa pemeriksaan atas kematian tidak wajar yang berbasis pada autopsi forensik mempunyai nilai kesahihan yang dapat dipertanggungjawabkan kebenaran ilmiahnya.

Urgensi autopsi forensik dalam kasus kematian dapat dilihat pada kesimpulan hasil pemeriksaan sebagaimana dituangkan di dalam visum et repertum. Sebagaimana disebutkan pada bagian terdahulu, bahwa kasus kematian tidak wajar tanpa melalui pemeriksaan autopsi forensik, penyebab kematian korban tidak dapat disimpulkan. Antara perbuatan pelaku dengan penyebab kematian, haruslah ada hubungan kausal yang diperlukan dalam pembuktian perkara. Hakim dalam mencari hubungan sebab dan akibat harus menggunakan 
metode induktif, artinya dalam mengambil kesimpulan atas suatu peristiwa pidana yang sedang diperiksa, hakim harus memperhatikan, menelaah dan kemudian menilai semua faktor yang terjadi dalam suatu peristiwa, ${ }^{32}$ dan kemudian hakim menilai berdasarkan hubungan kausal antara perbuatan terdakwa sebagai penyebab yang menimbulkan akibat pada kematian korban.

Dalam praktiknya, kasus-kasus kematian yang korbannya tidak diautopsi perkaranya tetap dapat dilanjutkan pada tahap pemeriksaan pengadilan. Meskipun tanpa autopsi, apabila dalam fakta di persidangan dapat dibuktikan bahwa terdakwa bersalah berdasarkan alat bukti yang ada, maka terhadap terdakwa tetap dapat dijatuhi sanksi pidana atas kasus peristiwa kematian, sebagaimana Putusan Pengadilan Negeri Donggala Nomor 17/Pid.Sus/2018/ PN.Dgl, dalam kasus kecelakaan lalu lintas yang mengakibatkan korban meninggal dunia.

Dalam pemeriksaan pengadilan, Visum et Repertum Nomor: 445/207A/ ER/RSUD/XI/2017 tanggal 28 November 2017, yang dikeluarkan oleh Rumah Sakit Umum Daerah Tambu Kecamatan Balaesang Kabupaten Donggala, dalam kesimpulannya menyebutkan, bahwa dari hasil pemeriksaan ditemukan beberapa luka lecet di daerah kepala dan anggota gerak, disertai luka robek pada anggota gerak atas sebelah kanan; penyebab kematian diduga akibat benturan pada kepala, namun penyebab pasti kematian tidak dapat disimpulkan, karena tidak dilakukan autopsi. Pada prinsipnya seseorang yang melakukan perbuatan pidana akan dipidana apabila terbukti secara sah dan meyakinkan melakukan kesalahan, ${ }^{33}$ meskipun penyebab kematian bersifat dugaan yang belum pasti kebenarannya, hakim berdasarkan fakta yang terungkap di persidangan Putusan Nomor 17/Pid.Sus/2018/PNDg1, memutuskan terdakwa bersalah dan menjatuhkan sanksi pidana penjara selama 9 (sembilan) bulan.

Visum et Repertum Nomor: 445/207A/ER/RSUD/XI/2017 sebagai sarana dalam menentukan penyebab kematian korban dalam Putusan Nomor 17/Pid.Sus/2018/PNDgl, dapat disandingkan dengan kasus meninggalnya Kepala Kesatuan Intelijen Polres Bogor yang bertugas mengamankan unjuk rasa mahasiswa tanggal 9 Mei 1998. Dugaan awal kematian korban dikarenakan pukulan batu di kepala yang dilakukan oleh beberapa oknum mahasiswa, kemudian korban dibawa ke RS Ciawi dan selanjutnya dipindahkan ke RS PMI Bogor, namun korban meninggal dunia satu jam kemudian, dan empat jam kemudian dilakukanlah autopsi forensik, dengan kesimpulan penyebab kematian korban dikarenakan penyakit jantung koroner. ${ }^{34}$

Menurut hemat penulis, kesimpulan dalam Visum et Repertum Nomor: 445/207A/ER/RSUD/XI/2017 dalam Putusan Nomor 17/Pid.Sus/2018/PNDgl, tidak dapat menyimpulkan hubungan kausal antara penyebab kematian dengan kondisi luka lecet di kepala dan anggota gerak, luka robek pada anggota gerak atas sebelah kanan, sebagai dugaan penyebab kematian karena benturan pada kepala.

\footnotetext{
32 Andrio Jackmiko Kalensang, 'Hubungan Sebab Akibat (causaliteit) Dalam Hukum Pidana dan Penerapannya Dalam Praktek' (2016) 5 (7) Jurnal Lex Crimen 12.

33 M. Syarifudin Abadillah, 'Penerapan Asas Kausalitas Dalam Kecelakaan Lalu Lintas Yang Menyebabkan Korban Meninggal Dunia' (2020) 8 (5) Jurnal Kertha Semaya 800, 805.

34 Ohoiwutun, 'Urgensi Bedah Mayat Forensik Dalam Pembuktian Tindak Pidana Pembunuhan Berencana Kajian Putusan Nomor 79/Pid.B/2012/PN.BGR' (n 8) 84.
} 
Kesimpulan mengenai dugaan kematian disebabkan benturan pada kepala, dihasilkan dari pemeriksaan luar mayat dan fakta terjadinya peristiwa kecelakaan lalu lintas. Hal ini berbeda dengan kesimpulan dalam visum et repertum atas kematian anggota Polres Bogor, meskipun fakta di lapangan telah terjadi pengeroyokan terhadap korban, namun demikian hasil autopsi forensik dapat menemukan bahwa penyebab kematian dikarenakan penyakit jantung koroner. Atau dapat dikatakan, bahwa kebenaran materiil dalam kasus kematian tidak wajar hanya dapat diungkap dengan dilakukannya autopsi forensik.

Fakta peristiwa lain dalam kecelakaan lalu lintas yang berakibat pada kematian korban dapat kita lihat dalam Putusan Pengadilan Negeri Mojokerto Nomor 424/Pid.Sus/2018/PN.Mjk yang diputus tanggal 22 Oktober 2018. Perkara diperiksa antara lain berdasarkan alat bukti surat Visum Et Repertum Jenazah Nomor: XXIV/V/VER/2018 tanggal 24 Mei 2018 yang dikeluarkan oleh Rumah Sakit Umum Daerah dr. Wahidin Sudiro Husodo, Kota Mojokerto. Kesimpulan dalam visumet et repertum melalui pemeriksaan autopsi forensik, menyatakan bahwa ditemukan luka pada kepala, lebam kedua mata kanan dan kiri, luka jahitan di kepala bagian atas dengan 12 (dua belas) jahitan, kesimpulan bahwa, kematian korban diakibatkan trauma tumpul pada kepala yang mengakibatkan cedera otak berat dan pendarahan dalam kepala.

Putusan Nomor 424/Pid.Sus/2018/PN.Mjk dapat disandingkan dengan Putusan Nomor 17/Pid.Sus/2018/PN.Dgl, sepanjang terkait dengan hasil kesimpulan dalam visum et repertum atas mayat. Putusan Nomor 424/Pid.Sus/2018/PN.Mjk dapat disimpulkan penyebab kematian korban, yaitu diakibatkan trauma tumpul pada kepala yang mengakibatkan cedera otak berat dan pendarahan dalam kepala; sedangkan Putusan Nomor 17/Pid.Sus/2018/ PN.Dgl hasil kesimpulan atas pemeriksaan mayat menyebutkan, bahwa penyebab kematian diduga akibat benturan pada kepala, namun penyebab pasti kematian tidak dapat disimpulkan. Hasil kesimpulan tanpa autopsi forensik bersifat dugaan penyebab kematian yang pada hakikatnya masih harus diuji kebenarannya.

Sebagai alat bukti, visum et repertum tidak dapat berdiri sendiri, karena hakim dalam memutuskan pemidanaan harus didasarkan minimal dua alat bukti yang sah disertai adanya keyakinan hakim. ${ }^{35}$ Visum et repertum sebagai alat bukti dalam Putusan Nomor 17/Pid.Sus/2018/PN.Dgl tetap mempunyai nilai dalam pembuktian, dan hakim di dalam memutus perkara telah memenuhi ketentuan minimal alat bukti sebagaimana ditentukan undang-undang, namun demikian, dapat dikatakan keputusan hakim belum memenuhi tujuan penemuan kebenaran materiil sebagaimana dituju dalam pemeriksaan perkara pidana.

Dalam menyelenggarakan peradilan, hakim menerapkan hukum yang bersifat abstrak pada peristiwa yang konkret, ${ }^{36}$ dan hakim dalam Putusan Nomor 17/Pid.Sus/2018/PN.Dgl dalam memutus perkara telah menerapkan hubungan kausal dengan menggunakan logika dalam menilai dan menentukan adanya hubungan kausal antara perbuatan terdakwa dengan akibat kematian korban dalam peristiwa kecelakaan lalu lintas. Dalam praktik beracara penerapan ajaran

\footnotetext{
$35 \quad$ Lisdayanty (n 21) 277.

36 Siti Malikhatun Badriyah, Sistem Penemuan Hukum Dalam Masyarakat Prismatik (Sinar Grafika 2016) 79.
} 
kausalitas sangat penting, untuk tujuan ketepatan dan keberimbangan dalam putusan, sehingga dapat memenuhi rasa keadilan bagi korban, pelaku dan juga masyarakat. ${ }^{37}$ Putusan Nomor 424/Pid.Sus/2018/PN.Mjk yang didasarkan pada kesimpulan penyebab pasti kematian korban, merupakan justifikasi secara materiil yang dapat diuji kebenarannya secara ilmiah berdasarkan ilmu kedokteran yang telah teruji, yang bermanfaat dalam memenuhi tujuan penemuan kebenaran yang sejati atau kebenaran yang hakiki di dalam pemeriksaan perkara pidana.

\section{PENUTUP}

KUHP Pasal 222, KUHAP Pasal 133 dan Pasal 134, UU Kesehatan Pasal 122, Instruksi Kapolri Tahun 1975, dan SE Menkes Tahun 2001, merupakan ketentuan hukum mengenai autopsi forensik. Namun demikian, ketentuan adanya pemberitahuan dari penyidik pada pihak keluarga korban untuk pelaksanaan autopsi forensik, merupakan kendala tersendiri dalam implementasinya; dan sebagai sumber hukum pidana formil, KUHAP tidak memberikan kepastian hukum untuk dapat dilaksanakan autopsi forensik apabila ada penolakan dari pihak keluarga korban. Sebagai tindak pidana yang diformulasikan secara materiil, autopsi forensik sangat penting untuk memastikan penyebab kematian, karena akibat kematian merupakan unsur tindak pidana. Meskipun tanpa autopsi forensik tidak menjadikan terdakwa bebas apabila kesalahan terdakwa dapat dibuktikan berdasarkan alat bukti yang sah, namun demikian tujuan menemukan kebenaran materiil tidak terpenuhi tanpa autopsi forensik dalam kasus kematian tidak wajar.

Sebagai akhir tulisan ini, penulis merekomendasikan, mengingat urgensi autopsi forensik untuk kasus-kasus kematian tidak wajar, seyogianya autopsi forensik dapat dilakukan dalam setiap kasus kematian mendadak. Kemudian, mengingat pentingnya autopsi forensik dalam pembuktian kasus perkara kematian untuk mencapai tujuan kepastian hukum yang adil, seyogianya autopsi forensik dapat dilaksanakan, meskipun ada penolakan dari keluarga korban, karena hanya dengan autopsi forensiklah penyebab pasti kematian seseorang dapat ditemukan dan dipertanggungjawabkan secara ilmiah menurut ilmu kedokteran yang telah teruji kebenarannya.

\section{DAFTAR REFERENSI}

\section{Buku}

Afandi D, Visum et Repertum Tata Laksana dan Teknik Pembuatan (ed. 2, Fakultas Kedokteran Universitas Riau 2017).

Badriyah SM, Sistem Penemuan Hukum Dalam Masyarakat Prismatik (Sinar Grafika 2016).

Danis D, Kamus Istilah Kedokteran (ed. 1, Gitamedia Press 2009).

37 Lila Yurifa Prihasti, Tindak Pidana Penganiayaan yang Disertai Dengan Perkosaan dan Pencurian yang Dilakukan Oleh Anak Mengakibatkan Matinya Para Anak Korban (Studi Kasus Perkara Nomor 25.Pidsus.An/2014/PT.Sby)' (2018) 3 (1) Jurnal Panorama Hukum 73, 83. 
Henky, Yulianti K, Alit IBP, dan Rustyadi D, Buku Panduan Belajar Koas Ilmu Kedokteran Forensik dan Medikolegal (cet. 1, Udayana University Press 2017).

Hiariej EOS, Prinsip-prinsip Hukum Pidana (ed. 2, Cahaya Atma Pustaka 2016).

Idries AM, Indonesia X'file Mengungkap Fakta dari Kematian Bung Karno Sampai Kematian Munir (ed. 1, Mizan Publika 2013).

Ohoiwutun YAT, Imu Kedokteran Forensik Interaksi dan Dependensi Hukum Pada Ilmu Kedokteran (ed. 1, Pohon Cahaya 2016).

Sofian A, Ajaran Kausalitas Hukum Pidana (cet.1, Prenada Media Group 2018).

\section{Jurnal}

Abadillah MS, 'Penerapan Asas Kausalitas Dalam Kecelakaan Lalu Lintas Yang Menyebabkan Korban Meninggal Dunia' (2020) 8 (5) Jurnal Kertha Semaya.

Alviolita F P, 'Pertanggungjawaban Pidana Pengurus Korporasi Dikaitkan Dengan Asas Geen Straf Zonder Schuld' (2018) 3 (1) Jurnal Refleksi Hukum.

Kalensang AJ, 'Hubungan Sebab Akibat (causaliteit) Dalam Hukum Pidana dan Penerapannya Dalam Praktek' (2016) 5 (7) Jurnal Lex Crimen.

Kastubi, 'Fungsi Bedah Mayat Forensik (Autopsi) Untuk Mencari Kebenaran Materiil Dalam Suatu Tindak Pidana' (2016) 13 (1) Jurnal Spektrum Hukum.

Laksmi PP, Alit IBP, dan Henky, 'Deskripsi Faktor-Faktor Yang Memengaruhi Penolakan Otopsi Pada Kasus Kematian Yang Diduga Tidak Wajar' (2020) 9 (7) E-Jurnal Medika Udayana.

Lisdayanty, 'Kedudukan Visum et Repertum Dalam Pengungkapan Delik Pembunuhan di Wilayah Hukum Polrestabes Makassar' (2019) 2 (2) Jurnal Phinisi Integration Review.

Ohoiwutun YAT, 'Urgensi Pemeriksaan Kedokteran Forensik pada Fase Penyelidikan dan Penyidikan Perkara Pidana' (2014) 1 (2) Jurnal Cendekia Waskita.

Ohoiwutun YAT, 'Urgensi Bedah Mayat Forensik Dalam Pembuktian Tindak Pidana Pembunuhan Berencana Kajian Putusan Nomor 79/Pid.B/2012/PN.BGR' (2016) 9 (1) Jurnal Yudisial.

Poluan Y, 'Bedah Mayat dan Akibat Hukumnya' (2014) 3 (4) Jurnal Lex Crimen.

Prihasti LY, 'Tindak Pidana Penganiayaan yang Disertai Dengan Perkosaan dan Pencurian yang Dilakukan Oleh Anak Mengakibatkan Matinya Para Anak Korban (Studi Kasus Perkara Nomor 25.Pidsus.An/2014/PT.Sby)' (2018) 3 (1) Jurnal Panorama Hukum.

Rompas AF, 'Kajian Yuridis Pasal 134 KUHAP tentang Bedah Mayat Dalam Penegakam Hukum Pidana Indonesia' (2015) 3 (1) Jurnal Lex et Societatis.

\section{Website}

Ahmad Sofian, 'Ajaran Kausalitas dalam RKUHP' (Aliansi Nasional Reformasi KUHP 1 April 2016) <http://reformasikuhp.org/ajaran-kausalitas-dalam-r-kuhp/> diakses 17 Februari 2021. 
Addina Zulfa Fa'izah, 'Tabir Gelap Kematian Editor Metro TV Fakta Baru Mulai Terungkap' (Merdeka.Com, 22 Juli 2020) <https://www.merdeka.com/ trending/tabir-gelap-kematian-editor-metro-tv-fakta-baru-mulai-terungkap. html? page $=7>$ diakses 13 Februari 2021 .

Yogi Ernes, 'Polisi Ungkap Hasil Autopsi Jenazah Editor Metro TV yang Tewas di Ulujami' (DetikNews, 13 Juli 2020) <https://news.detik.com/berita/d5091632/ polisi-ungkap-hasil-autopsi-jenazah-editor-metro-tv-yang-tewas-diulujami> diakses 13 Februari 2021.

Galih Priatmojo dan Bagaskara Isdiansyah 'Penyebab Kematian Editor Metro TV Terungkap, Keluarga Tak Yakin' (Suarajogja.id 25 Juli 2020) $<$ https://jogja.suara.com/read/2020/07/25/164000/penyebab-kematianeditor-metro-tv-terungkap-keluarga-tak-yakin?page=all> diakses 13 Februari 2021.

\section{Putusan Pengadilan}

Mahyudin Siregar, Nomor 486/Pid.Sus/2014/PN.PSP, Pengadilan Negeri Padangsidempuan, 20 Januari 2015.

Hendri panggilan Hen, Nomor 40/Pid.Sus/2018/PN Pyh, Pengadilan Negeri Payakumbuh, 24 Mei 2018.

Kusnadi bin Rajab Nomor 2/Pid.B/2018/PN Pso, Pengadilan Negeri Poso, 8 Maret 2018.

Puji Teguh Hartono, Nomor17/Pid.Sus/2018/PNDgl., Pengadilan Negeri Donggala, 22 Maret 2018.

MukhlisSetiawan bin KhoirulHuda, Nomor 424/Pid.Sus/2018/PNMjk, Pengadilan Negeri Mojokerto, 22 Oktober 2018.

Marodjahan Simanjuntak vs. Pemerintah Republik Indonesia Cq. Presiden Republik Indonesia Cq. Kepala Kepolisian R.I. Cq. Kepala Kepolisian Daerah Sumatera Utara Cq. Kepala Kepolisian Resor Kota Besar Medan Cq. Kanit Reskrim Polrestabes Medan Cq. Kepala Kepolisian Sektor Medan Kota Cq. Penyidik Kepolisian Sektor Medan Kota atas nama Anas Hasibuan, Nomor 85/Pid.Pra/2019/PN Mdn, Pengadilan Negeri Medan, 9 Desember 2019.

\section{Peraturan Perundang-Undangan}

Undang-Undang Republik Indonesia Nomor 1 Tahun 1946 tentang Peraturan Hukum Pidana.

Undang-Undang Republik Indonesia Nomor 8 Tahun 1981 tentang Kitab undangundang Hukum Acara Pidana.

Undang-Undang Republik Indonesia Nomor 36 Tahun 2009 tentang Kesehatan.

Instruksi Kapolri Nomor Pol INS/E/20/IX/75 tentang Tata Cara Permohonan/Pencabutan Visum etRepertum.

Surat Edaran Menteri Kesehatan Nomor 1342/MENKES/SE/XII/2001 tentang Pelaksanaan Autopsi Forensik. 